\title{
SHELLS AND OTHER MARINE MATERIAL FROM TIKAL
}

\author{
Por Háttula Moholy-Nagy. \\ University of Pennsylvania, Tikal Project.
}

Excavations at Tikal, Petén, Guatemala, have produced a large quantity of marine and lacustrine material. All of the marine material had to be imported since Tikal is an inland site. It is about 175 air-kilometers from Tikal east to the Gulf of Honduras, about 260 air-km. northwest to the Bay of Campeche, and about 380 air-km. south to the Pacific Ocean. We cannot say at this point if the marine materials were obtained indirectly through trade or directly through expeditions to the coasts. The probable sources for freshwater mollusks are the few large aguadas or waterholes in the immediate vicinity of Tikal, and Lake Petén-Itzá about 25 air km. to the south. There are no streams in this part of the Petén. Land snails of local species sometimes encountered in the excevation will be omitted here. There is, to date, no evidence of intentional deposition of land snails as offrings or of their utilization as ornaments or as food.

The quantity of imported lacustrine and marine material found at Tikal indicates it was of considerable cultural importance to the ancient inhabitants. Because much of the material was encountered in undisturbed, unmixed archaeological contexts, it is possible to speculate about functions and uses, and to note if any changes occurred through time.

This paper is restricted to the material from Tikal, although illustrated objects from other sites similar or identical to those from Tikal are referred to aid the reader. However, it is clear that the specific uses to which shells and marine material were put at Tikal were not peculiar to Tikal alone. Rather such uses seem to be typical of the entire Lowland Maya area and comparable to those in other parts of the Mesoamerican culture area. 
The incompleteness of our knowledge of the Tikal material is another consideration in omitting comparative material here. Excavation are still in progress. Not all of the excavated shells have been identified by experts. The results of future digging and future analysis may very well alter the picture presented here. Therefore, our data must be considered preliminary and our statements tentative.

The names used here are those published by Abbott (1954). Because these terms are subject to rapid change, some alreadypublished synonyms are given in parentheses.

Genera and species marked with an asterisk (*) were identified by the following experts: Dr. Horace G. Richard or Dr. R. Tucker Abbot of the Academy of Natural Sciences, Philadelphia; and Dr. William Clench, Dr. Ruth Turner, or Mr. Richard Johnson of the Museum of Comparative Zoology, Harvard University, Cambridge. Charles Grégoire, M. D., of Brussels, Belgium, confirmed the presence of freshwater clam shell in a late Preclassic problematical deposit (Grégoire, 1962: 3).

Most of the other identifications were made in the field by the writer and other members of the Tikal Project staff using the expertly-identified materials as the principal reference, supplemented by Abbott (ibid). Identifications were also made by the writer from the collections in the Museum of Comparative Zoology through the courstesy of Drs. Clench and Turner. All of these still remain to be checked by experts. Terms marked with a question-mark (?) are particularly tentative, uncheked, field identifications.

UNMODIFIED AND SLIGHTLY ALTERED SHELLS

Atlantic Coast species

Bivalves (Numbers refer to single valves)

Anadara tranversa Say * (Arca transversa) - 28 unmodified, 1 pierced for suspension.

Arca zebra Swainson * (Arca occidentalis) - 56 unmodified (Coe, 1959: Fig. 52, h; Proskouriakoff, 1962; Fig. 46,e).

Noetia ponderosa Say * (Arca ponderosa) - 22 unmodified.

Apolymetis intastriata Say (?) - 1 unmodified.

Chione cancellata Linné * -25 unmodified (ibid: Fig. 44,i).

Codakia orbicularis L. ${ }^{*}-5$ unmodified (perhaps the same as Dosinia concentrica, ibid: Fig. 46,c).

Dinocardium robustum Solander * (Cardium magnum, C. robustum) 34. unmodified (ibid: Fig. 46,a), 1 perforated. 
Trachycardium egmontianum Shuttleworth * (Cardium egmontianum) - 31 unmodified.

Trachycardium muricatum L. (Cardium muricatum) - 4 unmodified.

Mulinia, probably lateralis Say * - about 42 unmodified.

Musculus lateralis Say * -6 unmodified.

Pinctada, probably radiata Leach -2 unmodified (ibid: Fig. 46,d), Univalves 10 fragments, 4 worked pieces.

Busycon perversum L.* (B. contrarium) -2 unmodified (ibid: Fig. $47,0)$.

Cancellaria reticulata L. - 6 unmodified.

Conus spurius atlanticus Clench ${ }^{*}-1$ unmodified (ibid: Fig. 47,m).

Crepidula aculeatà Gmelin * - 35 unmodified.

C. fornicata L.* -8 unmodified.

Crucibulum auricula Gmelin - 22 unmodified.

Fissurella, probably barbadensis Gmelin - 1 unmodified.

Marginella, probably all apicina Menke - 3 unmodified, 4 pierced for suspension (Kidder, 1947: Fig. 82,b, right; Proskouriakoff, op. cit.: Fig. 44,d).

Murex pomum Gmelin - 1 unmodified.

Murex, probably florifer Reeve - 3 unmodified.

Oliva, probably reticularis Lamarck - 2 unmodified.

Oliva, probably sayana Ravenel - 1 unmodified.

Pleuroploca gigantea Kiener * (Fasciolaria gigantea) - 34 unmodified, immature (ibid: Fig. 47,r), 1 ground immature.

Polinices duplicata Say * -2 unmodified, 1 pierced for suspension (in same manner as Coe, op. cit.: Fig. 52,q).

Vasum capitellum L.* -1 unmodified.

Vermicularia spirata Phil.* — many fragments representing aboult 31 unmodified valves, 19 occurrences.

Xancus angulata Solander - 1 made into a trumpet.

\section{Pacific Coast species}

\section{Bivalves}

Lyropecten subnodosus Sowerby * (Pecten subonodosus) - 10 worked valves pierced for suspension.

Pseudochama echinata Broderip * (Chama echinata, Chama coralloides) - 28 unmodified (cf. KJS, 1946: Fig. 162,d), 4 worked.

Spondylus princeps Broderip * (S. crassisquama, S. pictorum, and probably S. limbatus) - 11 surely identified.

See Spondylus sp. below.

Univalves

Cerithium adustum Kiener * -1 unmodified.

Oliva porphyria L. - about 8, pierced for suspension (resembling Kidder, op. cit.: Fig. 85,d, 8-9).

Freshwater species 


\section{Bivalves}

Leptodon largillierti Phil.* -2 unmodified.

Univalves

Pachychilus, glaphyrus Morelet (Pachycheilus sp.) - 3 unmodified.

Pomacea, probably all flagellata Say* (Ampullaria flagellata) about 32 unmodified shells and 30 fragments.

Other marine shells (Genera occur in both the western

Atlantic and eastern Pacific Oceans)

\section{Bivalves}

Anadara (Lunarca) sp. - 12 unmodifield.

Arca $s p .^{*}-6$ unmodified, immature or fragmentary.

Anomalocardia sp. ${ }^{*}-8$ unmodified, immature.

Cardium sp." - 10 unmodified, immature.

Chama sp. - 15 small, weathered.

Tellin clams* -21 unmodified, immature.

Quahog-like clams." (some of these may be Venus campechiensis or Mercenaria campechiensis) - 4 unmodified, 1 pair perforated for suspension.

Glycymeris sp.* - 9 unmodified, immature, (cf. Proskouriakoff, op. cit.: Fig. 46,g).

Isognomon sp. -2 perforated for suspension.

Mytilus sp." - about 62 unmodified, immature.

Ostrea spp." - about 117 unmodified, small, probably representing more than one species.

Pecten sp. ${ }^{*}-1$ unmodified, immature.

Pinna sp." and Atrina sp. - Many fragments representing about 15 unmodified valves.

Plicatula sp.* - about 55 unmodified valves.

Spondylus sp. - 21 unmodified valves and fragments Coe, op. cit.: Fig. 52,j), 2 pairs perforated for binding together, 2 perforated fragments, 57 valves most perforated for suspension with most of the white interior lining scraped away (cf. KJS, op. cit.: Fig. $162, d$ ), some with hinges removed also (ibid: Fig. 52,o), about 21 immature valves perforated for suspension with ground and polished exteriors (Kidder, op. cit.: Fig. 82,a), about 500 small chips and fragments including many spines and pieces of the white inner lining, in 14, occurrences. Also a number of more extensively worked artifacts, listed below.

Unidentified marine bivalves - 48 unmodified, mostly small, immature specimens.

Unidentified nacreous shell fragments - about 15 small, apparently unmodified fragments of thick, pearly shell, probably of marine origin.

Univalves

Balanus sp." (Barnacles) - about 250 unmodified loose barnacles and many others attached to larger shells and beach pebbles.

Bulla sp.* - 3 small, unmodified. 
Busycon sp." - about 105 tiny, immature, unmodified.

Calliostoma sp.(?) - 5 unmodified.

Cassis sp. - 1 perforated for suspension.

Cerithium sp.* - 11 small, unmodified.

Conus sp. -3 unmodified (cf. Prokouriakoff, op. cit.: Fig. 47,m).

Crepidula sp. . -5 immature, unmodified.

Cyphoma sp. - rotted, possibly perforated for suspension.

Ficus sp. - 4 unmodified (cf. ibid.: Fig. 47,q).

Latirus sp.* -4 unmodified 2 cut lengthwiese. (cf. KSJ, op. cit.: Fig. 162,d).

Livonia sp. - 1 perforated for suspension.

Melongena sp.(?) -2 ground and slit valves (similar to Kidder, op. cit.: Fig. 48), 2 fragmentary valves with ground exteriors.

Nassa snails -5 unmodified.

Nerita sp. - 15 unmodified (cf. Proskouriakoff, op. cit.: Fig. 44,g). Oliva sp. -2 small, weathered, unmodified, 3 perforated for suspension (Kidder, op. cit.: Fig. 82,b, lower middle and Fig. 85,d,4). Most used as tinklers, described below.

Olivella sp. - 1 unmodified, 2 pierced for suspension.

Prunum sp. -2 picrced for suspension (possibly the same as Marginella labiata Val., cf. Proskouriakoff, op. cit.: Fig. 44,c).

Strombus sp. ${ }^{*}-3$ immature, unmodified. 1 possibly worked frag. ment.

Vermitidae fragments * -3 unmodified, unidentifiable fragments.

Unidentified marine univalves - 5 small, unmodified shells of one species, 16 small unmodified shells of another species, 9 small unmodified shells of various species, 2 columella fragments, 8 fragments with one or more cut edges, 1 small whole shell perforated for suspension.

\section{Other lacustrine shells}

Bivalves

Clams (family Unionidae) - about 40 fragments of thin nacreous shell, probably freshwater clam. Eleven perforated shells, including 5 paired valves, used as ornaments.

Other marine material (Exact sources unknown)

Corals - many small fragments in 18 occurrences (some like Coe, op. cit.: Fig. 52,d and like Proskouriakoff, op. cit.: Fig. 44,k) .

Hard sponge ("coral" or "bryozoan") — many fragments in 8 occurrences.

Soft sponge - about 10 fragments in 7 occurrences.

Gorgonians ("sea-plume") - about 15 fragments in 4 occurrences.

Coquina - unmodified lumps, 6 occurrences.

Sand dollar - 1 unmodified.

Pearls - 1 unmodified, 16 pierced for suspension in 6 occurrences (cf. Kidder, op. cit.: Fig. 84,a, 1).

Fossil casts * - 4, of ancient gastropods, in 2 occurrences.

Unidentified fibrous material of marine origin -4 occurrences. 
Bone of marine origin (Exact sources unknown)

Sting-ray spines - about 158 unmodified spines (ibid: Fig. 75 ) and fragments in 18 occurrences, and about 81 worked spines and fragments (Ricketson and Ricketson, 1937: Fig. 134, a; Kidder, op. cit.: Fig. 75 (one): Coe, op. cit.: Fig. 55,c,f; Proskouriakoff., op. cit.: Fig. $41, \mathrm{n}$, left ) in 8 occurrences.

Fish vertebrae - over 700 unmodified, in 14 occurrences.

Fish spines - over 200 in 5 occurrences. Tentatively identified as from the skin of the porcupine fish (Diodon sp.).

Scutes - about 84 in 3 occurrences.

\section{Effigies}

Imitation sting-ray spines - about 110 of bone, 2 apparently of wood, in 10 occurrences (some like Coe, op. cit.: Fig. 55,d,e).

\section{Artifacts of extensively worked shell}

Beads - 130 (cf. Kidder, op. cit.: Fig. 49,a-h; 86,a,c). 118 of thick, pink shell, presumably Spondylus. 12 of white marine or unidentified nacreous shell. (KJS, op. cit.: Fig. $63, \mathrm{f}$ ).

Pendants -2 . 1 carved of thick, pearly shell, 1 a tentatively identified fragment.

Spangles - 81 of Spondylus shell. (78 identical to ibid: 74, Fig. $161, b, c)$ from an Early Classic tomb burial.

L-shaped objects - 10 of thick, white marine shell (cf. Kidder, op. cit.: Fig. 56a,b,d). 8 found in pairs.

Tinklers - 22, all but 1 apparently of Oliva shell ( 1 probably $O$. sayana, the others weathered and probably of various species, 1 either Oliva or Conus).

All examples have had the spires cut off and have a cut or drilled suspension hole near the apex (cf. ibid: Fig. 85,d, 1-3, 5.7; Coe, op. cit.: Fig. $52, \mathrm{~s}, \mathrm{t}$ ).

Finger-rings -2 . Cut and polished sections of a marine univalve, probably Oliva.

Mosaic elements - exact number unknown, but hundreds recovered. Of pink Spondylus shell, white marine shell, and nacreous shell - often found together. Elements are usually plain, but may be carved, incised, or with painted details. Usually found associated with jade mosaic elements.

Mask elements -8 carved and incised pieces of unidentified, weathered marine shell formed the eyes and teeth of a solid jade mask found in a late Preclassic tomb burial (Coe and McGinn, 1963:29)

Figurines - about 291 (some like Ricketson and Ricketson, op. cit.: Pl. 67,e, 5-6; Thompson, 1939; Fig. 97,d,f; Coe, op. cit.: Fig. 51,f-h,o and Fig. 52,e-g). Small cut objects having the silhouette of a standing human figure. Usually with incised details, occasionally plain, or with details added in dull black paint. About 235 of Spondylus shell, 48 of white or nacreous shell.

Small worked objects - about 177 . By this term we mean cut, carved, incised, and/or painted objects of shell of uncertain use. Such 
objects have sometimes been called "adornos" (e. g., Kidder, op. cit: $65-66$, Figs. 53,a-c; 54,a; 55, and 85,a,b. Cf. also Thompson op. cit.: Pl. 29,c,1-8; Pl. 30,b,1; Coe, op. cit.: Fig. 51,t-v; Fig. 52,i,y-a'; Proskouriakoff, op. cit.: Fig. 42,j,n-p,r-s,u-x; Fig. 43,a top right),c). About 119 of Spondylus shell, including 24 with designs in dull black paint. About 58 of white marine or nacreous shell, including 7 with painted designs, and about 18 carved into flower-like and other forms (cf. Kidder, op. cit.: Fig. 85,a,10-15). Miscellaneous cut or perforated pieces and fragments (cf. Proskouriakoff, op. cit.: Fig. $43, \mathrm{~b}, \mathrm{~d}-\mathrm{f}$ ) about 44 fragmentary or undecorated pieces of worked shell, and 1 unmodified marine shell fragment decorated with polychrome-painted stucco. 12 pieces of Spondylus shell, 20 of pearly shell, 13 of white marine shell.

\section{Contexts}

Cached offerings associated with stelae or with structures of probable ceremonial function, tomb burials, and some of the minor burials associated with probable hierarchic structures are here referred to as ceremonial contexts. Minor burials associated with probable residential structures, and occupation debris - in middens, on floors, or redeposited as construction fillare considered non-ceremonial or secular contexts. The contexts, of course, suggest functions for the included objects. Sometimes, as in the case of the so-called problematical deposits ( $p .14$, below), the objects define the nature of the archaeological context.

Regarding ceremonial contexts, some of the symbolic connotations shells had for the Classic Maya discussed, for example by Thompson (1950), are of interest here.

Shells, particularly conch shells, symbolized the earth, the underworld, and the realm of the dead (ibid: 49). A representation of a shell added to the sun glyph converted it to a symbol for night (ibid: 49). On monuments, an inverted, conventionalized univalve shell represented south, associated with the death god an the underworld (ibid: 49, 85, 271). The conch shell was associated with the Mam, the old god of the interior of the earth and of the number five (ibid: 133-134). Conventionalized Oliva shells, and bivalves, sometimes in combination with the representation of a hand, symbolized completion and possibly zero (ibid: 138). Shells were occasionally used as ending glyphs (ibid: 192, 193). The idea of completion may have 
been equivalent to death (ibid: 186). However, shells were also symbolic of the moon goddess and procreation (ibid: 133-134).

Shells were also aquatic symbols. They represented water, the subterrestrial region, and the earth crocodile (ibid: 133$134,278)$. Red shell beads may have a connection with the Kan cross, which is also an aquatic symbol (ibid: 275, 276).

The invariable inclusion of shells in Tikal tomb burials, all of which were associated with ceremonial construction, and also in some minor burials associated with construction of probable ceremonial function, seems to conform to the gloomy symbolism of death, completion, and the underworld. The reason for their frequent occurrence in structure and monument caches is somewhat more difficult to explain at present.

\section{Monument caches}

Three "offertory assemblages" have been tentatively formulated for the offerings cached beneath Tikal stelae (Coe, 1962b: 497-498; to be more completely described in Tikal Reports $\left.\mathrm{N}^{\circ} 13\right)$.

In Long Count dates, according to the stelae with which they were associated, the Early offertory assemblage is earlier than about 9.4.0.0.0, the Transitional falls between about 9.4.0.0.0. and about 9.13.0.0.0, and the Late between about 9.13.0.0.0 and 10.2.0.0.0.

To date, 46 monument caches have been excavated: six Early, 13 Transitional, one Transitional or Late, 22 Late, and four of uncertain date. Five of the Early, seven of the Transitional, the Transitional or Late cache, one of the caches of uncertain date, and none of the Late caches contained shell or marine material. The situation is somewhat complicated by the fact that most of the Early and about half of the Transitional caches are associated with reset stelae, which leaves open the possibility that these caches were subject to disturbance at periods later than the Long Count dates given above, and that the cache contents may no longer represent an original pattern.

The frequency with which shells and marine material were placed in monument caches shows a proportionate decline from Early to Transitional caches, disappearing altogether in Late monument caches. One of the clearest trends noted at Tikal so 
far is the omission not only of shells but also of eccentric obsidians from Late monument caches, and the formulation of a highly standardized Late offering consisting of a set of nine incised obsidians of predictable design, deposited with a set of nine eccentric flints, some of predictable form (Coe, op. cit.).

The shells and marine material found in Early monument caches, although not as numerous or varied, show a close similarity to that found in Early structure-associated caches. The marine contents of the Transitional monument caches include items found also in both Early and Late structure caches, and in Early monument offerings.

\section{Structure caches}

In as much as analysis has not proceeded sufficiently, "offertory assemblages" have not been established for structureassociated caches. However, the caches may be broadly grouped according to the dates of associated construction (ibid: 498500). These dates are derived in part from ceramic style changes as known from Uaxactun (Smith, 1955: 106) and in part from superposition of architectural features temporally controlled in one manner or another.

Fifty-five structure caches, all associated with constructions of ceremonial function, are known from Tikal to date: two of late Preclassic, 32 of Early Classic, 19 of Late or probable Late Classic, and two of uncertain date. None of the Preclassic, 28 of the Early, 14 of the Late or probably Late, and one of the caches of uncertain date contained marine objects. The contents of these caches, in fact, comprise most of the unmodified shells known from Tikal.

Inherent beauty was evidently not an important criterion in the selection of unmodified shells for structure and monument caches. Often the shells are weathered, immature, or disfigured by growths of barnacles, coral, or gorgonians. While most are complete, and paired valves of bivalve shells seem to have been valued over single valves, broken shells were also occasionally offered.

An overall reduction in the size of the offerings and perhaps a slight standardization in the kinds of marine and other objects offered is a trend also apparent from Early to Late 
or more jade beads) and one or more sting-ray spines, either unmodified, trimmed, grooved, or carved. The contents of the Preclassic tomb are of particular interest for they establish the early ceremonial value of marine shells and sting-ray spines at Tikal.

Like the Early monument and structure caches, the Early Classic tomb burials contain more offerings than the Late ones. The marine offerings are those also characteristic of Early structure-associated caches. One exception, possibly of significance, is the immature Spondylus valve ground and polished on the exterior and perforated for suspension. These may only occur with burials of this time. The resemblances of marine offerings to those of Early structure caches was particularly marked in one Early Classic tomb burial (Shook and Kidder II, op. cit.). Among the offerings was a black, lidded, cylindrical cache vessel which contained a number of small unmodified marine shells - forming a sort of cache within the tomb itself.

In general, however, all known tomb burials contain much less unmodified shell and marine material and more worked shell than the contemporary structure caches. This seems particularly true of the Late Classic tomb burials.

\section{Minor burials}

Any interment in a grave other than a tomb, according to the working definition previously given, is referred to here as a minor burial. Several types of graves are undoubtedly included in this group.

One hundred and four minor burials have been excavated to date at Tikal. All but three were associated in groups of "small structures" of presumably residential function (Coe, op. cit.: 502 ) and in small outlying groups which included structures of probable ceremonial function. Only 20 of the minor burials contained any marine offerings. Twelve of these were associated with probable ceremonial structures: one may be Preclassic, three are Early Classic, six are Late Classic, and two are undated but fall somewhere within the Classic. The offerings with these 12 burials included more Spondylus shell and unmodified marine objects than did the offerings with the eight other 
minor burials associated with "small structures" of probable secular function. Of these eight, one is Early Classic and seven are Late Classic. Only worked shell objects were included with these eight non-ceremonial burials.

Some of the offerings found in minor burials resemble artifacts found in "small structure" occupation debris. Most, however, show no consistent resemblances to any other contexts, probably because of the present dearth of unmixed, non-ceremonial occupation debris at Tikal.

\section{Problematical deposits}

Marine and lacustrine materials also occur occasionally in contexts which are at present problematical for one or another reason. Such contexts include both homogeneous, intentional deposits and incidentally-constituted ones. The marine and lacustrine materials add no new information regarding the materials themselves because in most cases the objects have formed the bases for defining or dating the associated deposits.

Of the 72 problematical deposits defined at Tikal at present, ten contained objects of marine origin. Generally only lower-limit dates can be assigned to these: one is late Preclassic and is an intentionally-deposited collection of material ordinarily not found in structure or monument caches; two, found in chultuns, appear to be redeposited or disturbed minor burials of the Early Classic period; the remains of a redeposited tomb burial of Early Classic date forms all of another problematical deposit; the contents of yet another, together with Early structure cache materials, monument fragments, and a great deal of utilitarian pottery and artifacts comprises a fourth deposit with burial features. Two intentional deposits in Early Classic temples could be approximately contemporary or later; one from the replaced fill over a robbed Early Classic tomb burial dates to middle Late Classic times or later; one deposit of cache material found in backdirt probably pertains to a large Late structure cache nearby; while some material characteristic of either Early structure or monument caches occurred in construction fill laid down during the Late Classic period in an outlying ceremonial group (Coe and Broman, 1958: 34). 


\section{Occupation and undated debris}

At present most of the presumably secular occupation debris of Preclasic and Early Classic date occurs redeposited as construction fill in the ceremonial center of Tikal. Late Classic occupation debris often occurs unredeposited in groups of "small structures" of possible residenital function (Coe, op. cit.: 502504) as well as redeposited as fill. Some has also occurred in a Late Classic palace structure. The remains of a very late occupation, corresponding to the Tepeu 3 phase of the Uaxactun ceramic sequence (Smith, op. cit.), has occurred on the floors of two adjacent palace structures on the Central Acropolis. Other lots of shell-bearing debris, which cannot be dated, have appeared in the rooms, roofcomb chambers, and outside the walls of presumably residential and ceremonial structures, and in other isolated surface accumulations from nearly everywhere at the site.

All of this material, regardless of approximate age, is characterized by the complete absence, so far, of marine materials other than shells and of specialized ceremonial artifacts such as mosaic elements and imitation sting-ray spines, and the extreme rarity of unmodified marine shells, shell figurines, and beads of Spondylus shell. This, of course, somewhat strengthens the attribution of ceremonial values to the above-mentioned items, although the occasional presence of unmodified marine shells and perforated or scraped Spondylus fragments in and around the "small structures" is still to be explained.

Since artifacts of slightly- or extensively-worked shell are the usual finds, we might infer that the following were primarily ornamental in function: cut Oliva shell tinklers, beads of white marine or pearly shell, miscellaneous fragments of freshwater or marine shell with one or more cut edges, pairs of clam shells and small and medium-sized marine univalves perforated for suspension, small carved flower-like objects of white marine shell and other small objects of shell, and L-shaped objects.

\section{Representations of shells}

Fairly naturalistic representations of shells are occasionally found in Classic ceremonial contexts. Several large bivalves, 
probably Lyropecten, are depicted on Stela 4, of uncertain date but of Early Classic style (Coe, op. cit.:500) and on Stela 31 with a possible date of 9.4.0.0.0 (ibid: 491-492, 500, Fig. 7, 8). These shells perforated near the hinges like the Lyropecten subnodosus valves from an Early Classic tomb burial and an Early structure cache, are shown attached to necklaces, bracelets, and earplugs. Four wizened gnome-like figures, probably Mams, are shown emerging from what seem to be conch shells along the sides of Altar 4, which is Early Classic in style and type of stone. Three panels showing massed bivalve shells decorated the lid of a stucco-covered cylindrical tripod puttery vessel. The vessel comes from an Early Classic tomb which bears a date of 9.1.1.10.10 painted on one of the walls (Shook and Kidder II, op. cit.: 6). A bridge-spouted effigy jar, also decorated with painted stucco, represents a creature with the head of crested bird and the body of a conch shell (Coe, 1962a: Fig. 7). This pottery vessel was encountered in another tomb of Early Classic date.

Of Late Classic date are several representations of large, uncut Oliva shells perforated at the apex in the same way as about 8 Oliva porphyria shells found in a redeposited Early Classic burial (p. 15). These are shown attached in groups to the belts of the figures on Stela 21 (9.15.5.0.0), Stela 5 (9.15.13.0.0), Stela $20(9.16 .0 .0 .0)$, Stela 22 (9.17.0.0.0), and Lintel 2 of Temple III (style-dated between 9.16.10.0.0 and 10.1.10.0.0; Coe, Shook, and Satterthwaite, 1961: Table 3, Figs. 18, 19).

\section{Preferences, Functions, and Uses}

From the various archaeological contexts in which shells and marine material occur at Tikal, it can be inferred that they had two principal functions: symbolic and ceremonial, and ornamental and secular. Generally, ceremonial objects were interred as offerings; ornamental objects were articles of personal adornment. In this regard Tikal is representative of other Mesoamerican sites where clearly utilitarian objects of shell or marine material are practically absent. In addition to ceremonial and ornamental usages, some of the freshwater shells may have been collected for use as food. Pomacea flagellata 
are occasionally eaten in the Peten today. Although some objects seem to have had dual functions, materials of marine origin found in hierarchic or in secular contexts are usually quite distinct from each other.

The larger or more massive shells, such as Strombus, Busycon, Pinctada, Oliva, and many kinds of clams, can be worked into attractive ornaments. They probably were the sources of the artifacts of unidentified marine or nacreous shell previously mentioned. These kinds of shell, and most ornamental shell artifacts found at Tikal, usually occur in occupation debris or in deposits of problematical nature. They also occasionally occur as offerings in tomb and minor burials of the Late Classic period.

It is generally the smaller, more fragile, and more convoluted shells, the non-shell marine material, and bones of marine animals which were included in cached offerings. These shells and materials do seem unsuited for the manufacture of ornaments. They may have been valued only because they came from the sea, or -in the case of the lacustrine Pomaceabecause they were eaten. Sting-ray spines, sometimes, worked, are only found in ceremonial contexts at Tikal, and are generally considered as bloodletting instruments (cf. Coe, 1959:66). Imitation sting-ray spines, which sometimes occur in the same deposits, may have had the same functions. Another kind of clearly ceremonial artifact is the incised, plain, or painted shell figurine. Perhaps these are comparable in terms of symbolism to the eccentric flints and obsidians with which they were sometimes deposited (for anthropomorphic flints see e.g. Thompson, 1939: Pl. 24,c,3; for anthropomorphic obsidians see e.g. Coe, op. cit.: Fig. 28,o and Fig. 36,e).

Mosaic elements of shell, although certainly decorative in nature, have never to date been found apart from caches, tomb burials, or problematical deposits. While such tiny objects might be overlooked in excavations, their noted absence does suggest mosaic assemblages could well have been made for ceremonial deposition. The trumpet made from a large Xancus angulata can still be blown. However, the rarity of this artifact type at Tikal and the discovery of this one example perhaps intentionally buried in structure fill suggest it mos have had some ceremonial function. The ground Melongefo 
shells, to date only encountered in burials, are also of especially problematical function.

To conclude from its quantity and widespread distribution at Tikal (and in other parts of Mesoamerica), Spondylus shell seems to have been valued over all other kinds for both ceremonial and ornamental use. However, although Spondylus usually occurs in ceremonial contexts, entirely unmodified valves are extremely rare. Usually the valves are scraped on the interior, and a few from Early Classic burials are ground on the exterior. Most of the votive figurines, small worked objects, beads, and mosaic elements are of Spondylus shell. Quantities of tiny chips are common in Early structure caches. The Spondylus beads and worked valves may have been objects with dual functions. They were shaped or modified to bring out the red color of the shell, and the almost invariably-present perforations indicate ornaments. But their nearly exclusive occurrence in caches and major burials also suggests symbolic values (p. 8).

No shell material has to date appeared in contexts identifiable as workshops. Regarding one fairly common type of shell artifact, the cut Oliva shell tinkler, the complete absence of any fragments of the removed spires suggests tinklers were not manufactured at Tikal. On the other hand, quantities of cached Spondylus chips, small unmodified shell fragments, and fragments with one or more cut edges might all be indications of the local manufacture of at least a few types of shell artifacts.

\section{Chronological distribution and summary}

Shells and marine materials have an apparently uninterrupted temporal distribution at Tikal from at least late Preclassic times to the early part of the Postclassic. According to the associated ceramics, this is approximately equivalent to a period from the Chicanel phase through the Tepeu 3 phase at Uaxactun (Smith, op. cit.).

Objects from late Preclassic contexts already manifest two characteristics also encountered in later periods: importation and utilization of shells of both marine and lacustrine species, and differentiation between materials used for ceremonial and for ornamental purposes. The latter is known from the contents 
of a tomb burial (Coe and McGinn, op. cit.) which already conform to a pattern of tomb offerings which continues into the Late Classic (as late as the Tepeu 2 phase of the Uaxactun sequence).

With the apparent increase of ceremonial activities during Early Classic times, there seems to have been increased importation and use of marine materials. Representations of shells occur on monuments and pottery. The practice of including objects of marine origin with cached offerings associated with stelae and ceremonial structures may have been initiated at this time. Specialized artifacts of ceremonial function often appear in these caches (p. 11) and occasionally in tomb burials. Early structure and monument caches, tomb and minor burials, and a few problematical deposits are the principal sources of shell and marine material, and suggest a generalized assemblage which served in all hierarchic contexts. However, at present even less is known of the non-hierarchic use of shells (and other materials and artifacts) during the Early Classic than during the preceding period.

There is an apparent concentration of Pacific Coast species in Early Classic ceremonial contexts. The only exceptions identified so far are scraped valves of Spondylus princeps which continue to appear, perhaps as heirlooms, in Late Classic tomb burials. Although many of the Tikal shells remain unspecified at this writing and future work may change the picture, contact with the Pacific Coast seems to have reached its peak during Early Classic times. It was then that "Teotihuacan" traits appeared in ceremonial contexts. The apparent concentration of Pacific Coast shells at this time is probably a related phenomenon (Coe, 1962b: 499-500).

The spatial distribution of shells and marine objects became more differentiated and standardized during the Late Classic. In general, caches and burial offerings are not only different from those of the Early Classic, but also show divergence between themselves (ibid: 498-499). Unmodified marine shells are practically only found in situ in structure caches, which now also contain more non-shell marine materials. The specialized ceremonial objects of Early Classic times are almost absent. Representations of perforated, uncut Oliva shells occur on Late Classic monuments and on one carved lintel, although curiously our single find to date of Oliva shells worked in this manner 
comes from the offerings of an Early Classic tomb burial redeposited at an unknown date. Since more occupation debris of this period has been excavated, more is known about ornamental shell artifacts. Some of these are also found in tomb and minor burials. Beads of shell other than Spondylus, as well as L-shaped objects and carved small shell objects, may not have appeared at Tikal before the begining of Late Classic times. All of the other types of ornamental shell artifacts found in occupation debris (p. 16) are at least as old as the late Preclassic.

The cessation of ceremonial construction and of the periodic erection of monuments are two of the events which are taken to mark the end of Classic Tikal. Unsurprisingly, the small amount of shell material which can be dated as Postclassic comes from occupation debris. The few objects, all of worked shell, seem to represent a late carry-over of some of the ornamental artifacts found in Late Classic non-ceremonial contexts.

\section{REFERENCES}

Аввотт, R. T.: American Seashells. D. Van Nostrand Company, New York. 1954.

Coe, W. R.: Piedras Negras Archaeology: Artifacts, Caches, and Burials. Museum Monographs, University Museum, Philadelphia. 1959. Excavations and Splendid Finds at Mayan Tikal, Guatemala. Part II. Illustrated London News, Vol. 24.0, No 6391, pp. 135-137, London. 1962a.

A Summary of Excavation and Research at Tikal, Guatemala: 1956 1961. American Antiquity, Vol. 27, № 4, pp. 479-507, Salt Lake City. 1962b.

and V. L. Broman: Excavations in the Stela 23 Group. Tikal Reports No 2, Museum Monographs, University Museum, Philadelphia. 1958.

and J. J. McGinn: The North Acropolis of Tikal and an Early Tomb. Expedition, Vol. 5, № 2, pp. 24-32, Philadelphia (in press). , E. M. Shook, and L. Satterthwaite: The Carved Wooden Lintels of Tikal. Tikal Reports No 6, Museum Monographs, University Museum, Philadelphia. 1961.

GRÉGoIRE, Charles: Further Studies on Structure of the Organic Components in Mother-of-pearl, especially in Pelecypods (Part I). Institut royal des Sciences naturelles de Belgique, Bulletin, Vol. 36, No 23, Brussels. 1960

KIDDER, A. V.: The Artifacts of Uaxactun, Guatemala. Carnegie Instituion of Washington, Publication 576. Washington. 1947. 
J. D., Jennings, and E. M. Shook (referred to as KJS) Excavations at Kaminaljuyu, Guatemala. Carnegie Institution of Washington, Publication 561. Washington. 1946.

Proskouriakoff, Tatiana: The Artifacts of Mayapan. In H. E. D. Pollock et al, Mayapan, Yucatán, México. Carnegie Institution of Washington, Publication 619. Washington. 1962.

Ricketson, O. G., and E. B. Ricketon: Uaxactun, Guatemala: Group E-1926-1931. Carnegie Institution of Washington, Publication 477, Washington. 1937.

SHook, E. M., and A. KIDDER II: The Painted Tomb at Tikal. Expedition, Vol. 4, N 1, pp. 2-7, Philadelphia. 1961.

Smith, R. E.: Ceramic Sequence at Uaxactun, Guatemala. Midlle American Research Institute, Publication 20, Tulane University, New Orleans. 2 volumes. 1955.

Thompson, J. E. S.: Excavation at San José, British Honduras. Carnegie Institution of Washington, Publication 506, Washington. 1939. Maya Hieroglyphic Writing. Carnegie Institution of Washington, Publication 589, Washington. 1950.

Tikal Report № 13, dealing with the cached offerings of Tikal, by W. R. Coe and H. Moholy-Nagy (in preparation). 